\title{
Copyright protection of illegal street and graffiti artworks Dr Paula Westenberger
}

\section{Introduction}

Although graffiti and street art are now increasingly done with permission of councils or building owners, and indeed monetized, ${ }^{1}$ the practice has originated illegally and is still often practiced without permission, illegality being one of the defining and attractive aspects of graffiti practice. ${ }^{2}$ Dictionary definitions of graffiti make specific reference to its illicit nature, defining it as: "writing or drawings scribbled, scratched, or sprayed illicitly on a wall or other surface in a public place." ${ }^{3}$ Unfortunately, while some countries ${ }^{4}$ have recognized the enforceability of copyright in relation to illegal graffiti, ${ }^{5}$ in other countries illegal or immoral artworks may not be protected by copyright for reasons of public policy and doctrines such as the "unclean hands" doctrine, which may potentially be applicable to illegal graffiti works. ${ }^{6}$ The first approach may impose excessive burden to the parties affected by the graffiti if a

\footnotetext{
${ }^{1}$ See for example the chapter 'Copyright in street art and graffiti: an Australian perspective' by Mark Davison in this volume.

${ }_{2}^{2}$ According to Marta Iljadica, "graffiti writing is distinguished not only by the use of letters or its style ${ }^{2}$ According to Marta Iljadica, "graffiti writing is distinguished not only by the use of letters or its style but also how it is done: illegally, in dangerous yet visible places. Indeed alongside the writing of names, illegality, as the history and structure of the graffiti subculture demonstrates, is one of the defining aspects of graffiti practice and may explain why graffiti writers eschew copyright laws in favour of the internal regulation of their creativity": Marta Iljadica, Copyright Beyond Law: Regulating Creativity in the Graffiti Subculture (Hart 2016) 12. Laura MacDiarmid and Steven Downing explore Canadian graffiti writers' transition into non-deviant lifestyles and careers, suggesting that this is often a back-and-forth process, in order to maintain relational ties in dominant culture and graffiti subculture, also noting the argument that "one must earn respect by starting with illegal tagging": Laura MacDiarmid and Steven Downing, 'A rough aging out: Graffiti writers and subcultural drift' [2012] 7(2) International Journal of Criminal Justice Sciences 605, 613-614. Jannes van Loon explain "most active graffiti writers produce both legal and illegal graffiti", that graffiti practitioners "almost always start with illegal graffiti activities", which can be associated with the process of developing one's individual style, and that many practitioners are motivated by the joy generated by its illegal nature: Jannes van Loon, 'Just writing your name?' An analysis of the spatial behavior of graffiti writers in Amsterdam.' (2014) 3 Belgeo 2, 6-7 and 10. See also Enrico Bonadio, 'Copyright protection of street art and graffiti under UK law' (2017) IPQ 211 and the chapter by Ronald Kramer in this volume.

${ }^{3}$ Oxford Living Dictionaries (English) $<$ https://en.oxforddictionaries.com/definition/graffiti $>$ accessed 23 December 2018.

${ }^{4}$ Although it is beyond the scope of this chapter to suggest detailed solutions for specific jurisdictions, the approaches adopted in some of the countries investigated in this collection will be analyzed in order to illustrate the issue and provide examples of best practices.

${ }^{5}$ See for example Germany, as discussed in the next section.

${ }^{6}$ See discussion in the next section on the approach in common law countries.
} 
balance is not reached in relation to conflicting rights, including the rights of owners of the building where the art was placed to whitewash or destroy the artwork. ${ }^{7}$ The latter approach could sanction the unauthorized commercial exploitation of illegal street art by third parties, leaving street artists without compensation for the use of their works.

This chapter argues for the need to effectively protect unauthorized graffiti by copyright law (both economic and moral rights) and puts forward the suggestion of treating it similarly to those cases where copyright protection is given to unauthorized derivative works.

This chapter will assess the extent to which denying copyright protection to illegal graffiti artworks contradicts the ethos of international copyright law, which this chapter argues is to provide protection to authors while promoting creativity. This analysis will be based on the requirements of and justifications for the protection of authors in international copyright and human rights laws, in particular the Berne Convention and the United Nations International Covenant on Economic, Social and Cultural Rights of 1966. In doing so, the chapter will discuss the rationales and requirements for copyright protection in such treaties that may justify the protection of illegal street art.

The chapter will then assess whether and how an optimal balance of interests may be reached that would best preserve such aims of international copyright law while securing conflicting legitimate interests of third parties such as property owners.

\footnotetext{
${ }^{7}$ The German case Re Pictures on the Berlin Wall [1997] ECC 553 offers a possible solution to this issue, as will be analysed below.
} 


\section{Mapping out the issue: the illegality of graffiti and street art and its impact in copyright subsistence, enforceability and moral rights}

\subsection{Illegality of content or form of placement?}

Illegality could relate either to content (e.g. immoral or hate speech) or form of placement of the graffiti or street artwork (e.g. vandalism or trespassing). The main discussion is whether public policy arguments and equity principles such as the "unclean hands" doctrine should apply to deny copyright protection. In relation to the content of the work, for example for obscene works, Canadian case law has decided "not to apply principles of common law and equity to attempt to restrain the dissemination of obscenity through a refusal of copyright" considering "the public policy considerations of encouragement of creativity, international protection of copyright and the flexibility in moral values". ${ }^{8}$ A similar approach allowing copyright protection of immoral content has been adopted in the United States, ${ }^{9}$ although "the circuits are not in total agreement regarding the application of unclean hands to copyright protection of unprotected content". ${ }^{10}$

In the UK, in the past, copyright protection has been denied or limited by the courts in view, for example, of the obscene and immoral nature of the content of the work, which could result either in findings that copyright did not subsist in the work, or that copyright could not be enforced, or else that no damages could be awarded. ${ }^{11}$ It is unclear whether public policy exclusions such as immorality would mean that no

\footnotetext{
${ }^{8}$ Aldrich v One Stop Video Ltd, [1987] BCJ No 1035, 39 DLR (4th) 362 (BCSC) at [94], but see below on the enforcement of rights. See also the chapter 'Graffiti, Street Art, Walls, and the Public in Canadian Copyright Law' by Pascale Chapdelaine in this volume.

${ }^{9}$ Mitchell Bros. Film Group, 604 F.2d 852 (5th Cir. 1979), citing U.S. Constitution art. 1, § 8, cl. 8: "Congress has concluded that the constitutional purpose of its copyright power . . . is best served by allowing all creative works (in a copyrightable format) to be accorded copyright protection regardless of subject matter or content, trusting to the public taste to reward creators of useful works and to deny creators of useless works any reward".

${ }^{10}$ Danwill Schwender, 'Promotion of the Arts: An Argument for Limited Copyright Protection of Illegal Graffiti' (2008) 55 J. Copyright Soc'y U.S.A. 257, 268.

${ }^{11}$ Bonadio (n 2) 215, with reference to the relevant case law.
} 
copyright subsist in the work, or whether it is unenforceable. ${ }^{12}$ While the CDPA 1988 "does not state that controversial subject matter is not eligible for copyright on grounds of public policy", ${ }^{13}$ it is possible that copyright may not be enforced based on the content of a work due to public policy reasons, as for example in a case of a "dishonest and misleading work" or a work of "grossly immoral tendency". ${ }^{14}$ The UK CDPA also includes a provision that may prevent or restrict copyright enforcement on public interests grounds, ${ }^{15}$ which the court in Hyde Park Residence Ltd $v$ Yelland has interpreted to allow courts not to enforce copyright where the work is for example immoral or scandalous. ${ }^{16}$ Such discussions on the level of protection offered by copyright based on the type of content of the work, however, would not concern graffiti any differently than it would concern any other work, which would require a wider study of public policy exclusions and the public interest defence in the UK that is beyond the scope of this chapter.

In relation to the United States, "harm to the public interest alone is insufficient to invoke the doctrine of unclean hands". ${ }^{17}$ The doctrine "is not applied where plaintiff"s misconduct is not directly related to the merits of the controversy between the parties, but only where the wrongful acts in some measure affect the equitable relations between the parties". ${ }^{18}$ This could mean that the effect of illegality in copyright protection would be better suited in cases where both parties are directly affected by the illegal conduct, for example in relation to the rights of the owner of a building where the graffiti was made to make use of their property, including for example to whitewash the graffiti, rather than morality arguments in relation to the content of the work. Therefore, considering that "the denial of protection for illegality seems steady

\footnotetext{
${ }^{12}$ Bently, Sherman et. al., Intellectual Property Law (5th edn, OUP 2018) 123; Gillian Davies, Kevin Garnett and Gwilym Harbottle, Copinger and Skone James on Copyright, vol 1 (17th edn, Sweet \& Maxwell 2016) (“Copinger”), para 3-432 arguing copyright subsists but may not be enforced.

${ }^{13}$ Bonadio (n 2) 215

${ }^{14}$ ZYX Music GmbH v King [1995] FSR 566, 577, citing Slingsby v. Bradford Patent Truck and Trolley Co. [1906] WN 51 ) and Glyn v. Weston Feature Film Co. [1916] 1 Ch. 261. See further discussion on this point below.

${ }^{15}$ Section 171(3), UK CDPA 1988: "Nothing in this Part affects any rule of law preventing or restricting the enforcement of copyright, on grounds of public interest or otherwise".

${ }^{16}$ Hyde Park Residence Ltd v Yelland [2000] 3 W.L.R. 215 [2001] Ch. 143.

${ }^{17}$ Schwender (n 10) 270.

${ }^{18}$ Keystone Driller Co. v. General Excavator Co., 290 U.S. 240, 245 (1933), as cited by Schwender at 269.
} 
Author's copy-please refer to the published version for the final text:

Paula Westenberger, "Copyright protection of illegal street and graffiti artworks" in Bonadio E (ed) Copyright in Street Art and Graffiti: A country-by-country legal analysis (CUP 2019)

concerning a plaintiff's illegal conduct", ${ }^{19}$ this chapter focuses on this aspect rather than the content of the graffiti or street art. ${ }^{20}$

What makes the case of graffiti worth studying from an illegality perspective in this chapter is the unauthorized placement of the graffiti, which is intrinsic to the nature and origins of this form of art, ${ }^{21}$ and directly impinges on the interests of the affected parties such as owners of property.

\subsection{Copyright subsistence or enforceability?}

Based on the jurisdictions analysed in this book, a distinction can be made between the approaches of civil and common law jurisdictions. Civil law countries tend to grant copyright protection regardless of whether the graffiti is done illegally, ${ }^{22}$ and attempt to resolve issues by balancing the competing interests. ${ }^{23}$

The countries where illegality may raise doubts as to whether copyright would protect graffiti artworks are predominately those of a common law tradition, where remedies

\footnotetext{
${ }^{19}$ Schwender (n 10) 268.

${ }^{20}$ Note here also Bonadio's chapter on the US legal scenario: "the illegal aspects do not even concern the content of the work - instead they regard the processes of creation of the piece".

${ }^{21}$ See for example the Oxford Living Dictionaries definition above (n 3). See also the discussion in Iljadica, above (n 2), 103: "Pornography or other obscene works are unlawful by virtue of their form and content, while graffiti writing is unlawful by virtue of its placement without permission on public and private property".

${ }^{22}$ In Germany, case Re Pictures on the Berlin Wall [1997] ECC 553: "It is not in principle relevant to the possibility of copyright protection by statute for the creation of a work that the way in which it was produced is evidently unlawful - in this case by virtue of an act of damage to property subject to civil and criminal sanctions" [at 8]. In France, there is no express provision in the French Code denying protection to illegal works, and the Court in the (Space) Invader case "did not appear to regard illegality as any obstacle when considering the originality of the work" (see the chapter "Graffiti, Street Art and Copyright in France' by Shane Burke in this volume). In Greece, although unauthorised street art is "very likely to be the result of illegal activity, they can remain copyright protected if the subsistence requirements are met" (see Chapter 15 by Stavroula Karapapa in this volume). In other countries, even though there has been no decision clarifying this subject yet, analogies could be made with the fact that copyright law does not deny protection to illegal or immoral artworks or based on public policy (see chapters in this volume by Enrico Bonadio and Gilberto Cavagna 'Copyright In Street Art And Graffiti: An Italian Perspective' and Marcela Palacio Puerta 'Graffiti, Street Art and Colombian Copyright Law').

${ }^{23}$ See e.g. France, Germany and Greece. In relation to France, it has been stated that this balancing approach 'is more typical of German law and that is somewhat at odds with the claimed absolutism of French principles' and '[w] here authorial rights conflict with legitimate rights in real property, a court will look favourably on the arguments of a building's owners seeking, as part of a restoration project, to demolish a work incorporated in the building.' See Elizabeth Adeney, The Moral Rights of Authors and Performers: An International and Comparative Analysis (OUP 2006) 191-192, as cited by Shane Burke in this volume (n 24).
} 


\section{Author's copy-please refer to the published version for the final text: \\ Paula Westenberger, "Copyright protection of illegal street and graffiti artworks" in Bonadio E (ed) \\ Copyright in Street Art and Graffiti: A country-by-country legal analysis (CUP 2019)}

are available on the basis of equity, and where the "unclean hands", illegality or public interest defences may apply. ${ }^{24}$ Whether these doctrines would affect copyright subsistence or only the enforceability of copyright, it appears that the latter is where the problem predominantly lies.

In Australia, remedies for injunction and account for profits are equitable, and therefore difficult to contemplate illegal graffiti; damages may be difficult to quantify and judges are likely to consider the plaintiff, who would have committed civil and criminal wrongs not having acted justly in relation to the property owner's interests thus it is more likely that legal graffiti and street art receives protection through the available remedies. ${ }^{25}$ In New Zealand, although no decision has established yet "whether a non-commissioned artwork attracts copyright and moral rights, or, if such rights exist, whether they are enforceable", it has been argued that the "court may use its inherent jurisdiction to deny or otherwise defeat a non-commissioned artist's suit for a remedy for a breach of their copyright and moral rights, relying on public policy, the equitable maxim of clean hands, or the common law ex turpi causa doctrine". ${ }^{26}$

In Canada, it is unclear whether copyright protects illegal graffiti or street art, for example those involving mischief or vandalism or the tort of trespass, as the legislation is silent in this respect. ${ }^{27}$ It appears that Canadian courts could refuse protection on the enforcement stage rather than not recognizing copyright subsistence. The court in Aldrich has recognized copyright subsistence, as mentioned above, but has restricted the remedies available to the copyright owner to injunctive relief and delivery up, having denied damages and account for profits. ${ }^{28}$ In relation to graffiti and street art produced illegally, for example by trespassing, it has been argued that it is unlikely that copyright subsistence would be denied, but there could be limits to the remedies available, where injunctions to stop infringement could be granted, while

\footnotetext{
${ }^{24}$ Danwill Schwender explains, in relation to the United States, that "Illegal conduct appears to be a form of unclean hands, but the courts and scholars have not discussed illegality to the extent of unclean hands." (n 10) 268

${ }^{25}$ See the chapter 'Copyright in street art and graffiti: an Australian perspective' by Marc Davison, in this volume.

${ }^{26}$ See the chapter 'Copyright, Graffiti, and Street Art in Aotearoa New Zealand' by Jonathan Barrett in this volume.

${ }^{27}$ See Pascale Chapdelaine (n 8).

${ }^{28}$ Aldrich v One Stop Video Ltd, paras 110-123. See Pascale Chapdelaine (n 8).
} 


\section{Author's copy-please refer to the published version for the final text: \\ Paula Westenberger, "Copyright protection of illegal street and graffiti artworks" in Bonadio E (ed) Copyright in Street Art and Graffiti: A country-by-country legal analysis (CUP 2019)}

damages may not be given as it would amount to profiting from an illegal act; alternatively courts could distinguish the Aldrich scenario from cases of commercial exploitation of illegal graffiti works and allow a possibility to recover damages or accounting for profit by viewing "the sale of dresses or books with the graffiti art as not an illegal act per se ... unlike in Aldrich, where the sale of obscene material as such was illegal", 29

In the United States, although the applicability of the unclean hands doctrine to deny copyright protection to illegal graffiti still remains unclear, this argument has been advanced in Villa v. Pearson Educ. Inc., where it is stated, in obiter dictum, that the argument for copyright protection "would require a determination of the legality of the circumstances under which the mural was created"). ${ }^{30}$ More recently, the dispute between Swedish retailer H\&M and street artist Revok illustrates how can this argument be put forward by a party accused of infringing copyright over an illegal graffiti artwork, but this case has been settled before a decision could be reached on this aspect. ${ }^{31}$ United States courts "have not directly stated that illegal conduct or circumstances will deny protection of copyright", and while Schwender has previously argued (although ultimately disagreeing with this approach) that the consensus was that works created under illegal circumstances were not protected, ${ }^{32}$ more recent commentary states that it is unclear or inconclusive whether illegally created graffiti is protected. ${ }^{33}$

\footnotetext{
${ }^{29}$ See Pascale Chapdelaine (n 8).

${ }^{30}$ Villa v. Pearson Educ. Inc., No. 03 C3717 (N.D. Ill. Dec. 8, 2003)

${ }^{31}$ For a summary of the dispute between H\&M and Revok, see: Enrico Bonadio, 'Big Brands Ripping off Street Art Is Not Cool: Why Illegal Graffiti Should Be Protected by Copyright' (The Conversation, 16 March 2018) <http://theconversation.com/big-brands-ripping-off-street-art-is-not-cool-why-illegalgraffiti-should-be-protected-by-copyright-93439> and Henri Neuendorf, "Street Artist Revok and H\&M Settle Dispute Over an Ad That Featured His Work Without Permission" (Artnet, 7 September $2018)<$ https://news.artnet.com/art-world/revok-hm-ad-campaign-1345127> (accessed 22 December 2018).

${ }^{32}$ Schwender (n 10) 268, citing Villa v Pearson Educ.

33 Danwill D. Schwender, Does Copyright Law Protect Graffiti and Street Art?, in Jeffrey Ian Ross ed., Routledge Handbook of Graffiti and Street Art (Routledge 2016) 453, noting however examples of cases where the illegality of the graffiti was not weighed in the copyright discussion, citing Reece $v$ Marc Ecko Unlimited 10 Civ. 02901 (JSR) (DF) (S.D.N.Y. Aug. 19, 2011) and Mager v Brand New School, 78 USPQ 2d 1389 (2004).See also: "it remains unclear whether copyright law affords protection for unauthorized street art": Lena Saltos and Angela Lelo (Hughes, Hubbard \& Reed, 11 January 2017) <https://www.hhrartlaw.com/2017/01/unchartered-territory-enforcing-an-artists-rightsin-street-art/> accessed 23 December 2018.
} 


\section{Author's copy-please refer to the published version for the final text: \\ Paula Westenberger, "Copyright protection of illegal street and graffiti artworks" in Bonadio E (ed) Copyright in Street Art and Graffiti: A country-by-country legal analysis (CUP 2019)}

In relation to the UK, the illegal placement of a graffiti artwork, which could constitute criminal damage, may trigger immorality, public policy and public interest grounds for refusing copyright enforcement, the rule against illegality, or refusal to award damages to the graffiti writer; there is no clarity however on how these would be applicable to illegal graffiti. ${ }^{34}$ These appear to mainly challenge enforceability rather than subsistence. ${ }^{35}$ Considering the possible scenarios, Iljadica notes that "illegality cannot automatically be equated to immorality", and that the law on the rule against illegality remains unsettled. ${ }^{36}$ Furthermore, although graffiti may constitute criminal damage, it is not clear it will be placed in one of the public interest categories for refusing copyright enforcement advanced by Aldous LJ in Hyde Park. ${ }^{37}$ If viewed narrowly, illegal graffiti relates to an offence against private property and not the public at large; if viewed more broadly, not only the increased popularity of graffiti can put in doubt the argument that it is injurious to public life, but also graffiti writers' actual motivations for the creation of graffiti do not suggest that copyright enforcement would incite others to do it. ${ }^{38}$

It is argued that copyright protection over street or graffiti art should not be denied on the basis that it is made illegally, particularly where the artwork is being used purely commercially by a third party. In Hyde Park, Aldous LJ stated that, as submitted by one of the parties, s 171(3) UK CDPA 1988 "should not be interpreted so as to interfere with a private property right without compensation", also accepting the

\footnotetext{
${ }^{34}$ See Iljadica (n 2) 102-107, explaining also that the public policy ground is related but not the same as the public interest defence. In Hyde Park Residence Ltd v Yelland [2001] Ch. 143; [2000] WL 462 Aldous LJ explains [at 63] the court's inherent jurisdiction to refuse to enforce copyright in cases where such enforcement would "offend against the policy of the law", citing Lord Mansfield CJ's in Holman v Johnson (1775) 1 Cowp 341 at 343, who said: "No court will lend its aid to a man who founds his cause of action upon an immoral or an illegal act." Laddie, Prescott and Vitoria, The Modern Law of Copyright (Lexis Nexis 2018) [21.25] argue for a limited application of the public interest defence in view of European law, and recognise the uncertainty in relation to the continued application of the defence.

${ }^{35}$ Laddie, Prescott and Vitoria (n 36) [21.29], when discussing copyright protection of unlawful works, argue that "copyright subsists but is unenforceable", based on the wording of s 171(3) UK CDPA 1988. See also Iljadica (n 2) 103 and discussion in 2.2.1 and (n12) above.

${ }^{36}$ Iljadica (n 2) 104 and 107.

${ }^{37}$ Iljadica (n 2) 106. Hyde Park Residence Ltd v Yelland [2001] Ch. 143; [2000] WL 462 [at 64]:"In my view a court would be entitled to refuse to enforce copyright if the work is: (i) immoral, scandalous or contrary to family life; (ii) injurious to public life, public health and safety or the administration of justice; (iii) incites or encourages others to act in a way referred to in (ii)." Although, as stated by Mance LJ in the same decision [at 82]: "the circumstances in which the public interest may override copyright are probably not capable of precise categorisation or definition".

${ }^{38}$ Iljadica (n 2) 106.
} 


\section{Author's copy-please refer to the published version for the final text: \\ Paula Westenberger, "Copyright protection of illegal street and graffiti artworks" in Bonadio E (ed) \\ Copyright in Street Art and Graffiti: A country-by-country legal analysis (CUP 2019)}

submission "that refusal of relief upon equitable principles is not a defence to an action for infringement of copyright under the 1988 Act." ${ }^{\text {39 }}$ In another case, public policy grounds were not applicable to deny enforcement of a work that infringed copyright (thus made illegally), the infringer being "entitled to prevent others pirating his work, subject to his obligation to account to the original author for his due share of any recovery." 40

This chapter argues that by analogy a similar understanding could be applied to illegally placed graffiti works. It appears unjustifiable to deny copyright protection in order to allow a purely commercial exploitation of a work without due payment, such as in the scenarios of commercial exploitation of illegal graffiti works like that of the Revok and H\&M dispute. Indeed, it would be "unfair to allow persons other than the artist to rely on the illegal nature of a street artwork to copy and exploit it for their own commercial purposes". 41

The conclusion that copyright could in principle protect illegally created graffiti can arguably be supported by the obiter comment by Justice Arnold in Creative Foundation v Dreamland that the copyright prima facie belonged to Banksy, despite of the fact that the artwork had been created without the prior knowledge nor the consent of the leaseholder and tenant. ${ }^{42}$ It is worth noting, however, that this case did not concern a copyright dispute, and therefore, albeit subsistence may have arguably been recognized, it is still not possible to conclude with certainty whether copyright would be enforceable in case a street artist had initiated a dispute on copyright grounds. ${ }^{43}$ It is my firm belief, however, that copyright could (and should) protect

\footnotetext{
${ }^{39}$ Hyde Park Residence Ltd $v$ Yelland [2001] Ch. 143; [2000] WL 462 [at 45]. The judgment provides various examples of possible scenarios where a public interest defence could be applied. See also Ashdown v Telegraph [2001] EWCA Civ 1142.

${ }^{40}$ ZYX Music GmbH v King [1995] FSR 566, 577, citing Laddie. Prescott and Vitoria, The Modern Law of Copyright and Designs (2nd edn), see para [21.31] of the 5th edn (n 36).

${ }^{41}$ Enrico Bonadio, 'Street Art, Graffiti and Copyright' in Bonadio and Lucchi, Non-Conventional Copyright: Do New and Atypical Works Deserve Protection? (Edward Elgar 2018) 105.

42 Ibid, 103.

${ }^{43}$ Creative Foundation v Dreamland concerned the severing of a piece of wall for the purpose of sale of the artwork, and thus it is unclear whether copyright would indeed have been infringed in the first place, apart from a possible discussion on whether the right of distribution (and related exhaustion issues) could apply (for a discussion on this matter, see the chapter by Pascale Chapdelaine in this volume). This, discussion, however, is not within the scope of this chapter, as it would also relate to legally made graffiti works.
} 


\section{Author's copy-please refer to the published version for the final text: \\ Paula Westenberger, "Copyright protection of illegal street and graffiti artworks" in Bonadio E (ed) Copyright in Street Art and Graffiti: A country-by-country legal analysis (CUP 2019)}

illegally created graffiti regarding both subsistence and enforcement, as will be further examined in section 3 .

\subsection{Moral rights}

Another relevant discussion in relation to illegal graffiti works are those actions by owners of property such as cleaning or destroying the unsolicited graffiti work, as these could raise moral rights issues. As this chapter is focused on illegal graffiti, the moral rights analysis will focus on the aspects that directly relate to the impact of illegality in the applicability of moral rights. In this respect, the crucial aspect appears to be whether the right of integrity is engaged in relation to actions of erasing (whitewashing) or destroying unsolicited graffiti works. Although this is a discussion that also applies in relation to legal graffiti, the possibility of engaging the right of integrity has arguably more severe consequences to property owners who have never authorized (or wanted) the artwork in the first place. ${ }^{44}$

In the United States, VARA may offer protection against the destruction of unauthorized graffiti if the art can be safely removed. ${ }^{45}$ A United States court has found that there was "no basis in the statute to find a general right to destroy works of art that are on property without the permission of the owner". ${ }^{46}$ In the UK, however, the general position in relation to the right of integrity (right to object to derogatory treatment), although with some degree of uncertainty, is that it does not apply to the destruction of the original embodiment of a work. ${ }^{47}$ Thus, in the UK, graffiti or indeed

\footnotetext{
${ }^{44}$ There are various discussions in relation to moral rights and graffiti more generally, which go beyond the scope of this chapter, such as whether change of placement engages the right of integrity.

${ }^{45}$ See English v. BFC\&R E. 11th St. LLC, No. 97 CIV. 7446 (HB), 1997 WL 746444, at *1 (S.D.N.Y. Dec. 3, 1997), aff'd sub nom. English v. BFC Partners, 198 F.3d 233 (2d Cir. 1999). The court found that "VARA does not apply to unauthorized works of art if the works are permanently affixed to the structure", see Lena Saltos and Angela Lelo 'Unchartered Territory: Enforcing an Artist's Rights in Street Art' (Hughes, Hubbard \& Reed, 11 January 2017) $<$ https://www.hhrartlaw.com/2017/01/unchartered-territory-enforcing-an-artists-rights-in-street-art/> accessed 23 December 2018. See also Danwill Schwender (n 10) 276-277, with an analysis of both English v. BFC\&R E. and Pollara v. Seymour, 150 F. Supp. 2d 393, 396 n.4. (N.D.N.Y. 2001).

${ }^{46}$ Pollara v. Seymour, 150 F. Supp. 2d 393, 396 n.4. (N.D.N.Y. 2001), although ultimately the case was decided on the artwork not being of a recognized stature, as required by VARA. For the possibility of graffiti being considered of a recognized stature, see the "5 Pointz" decisions: Cohen v. G\& $M$ Realty L.P., 988 F. Supp. 2d 212, 214 (E.D.N.Y. 2013) and Cohen et al. v G\&M REALTY L.P. et al., Case No. 13-CV-05612(FB) (RLM), decision of 12 February 2018.

${ }^{47}$ See Gillian Davies and Kevin Garnett, Moral Rights (2nd edn, Sweet \& Maxwell 2016) 245-246, also noting that it is generally accepted that destruction is not an aspect of the integrity right in article 6
} 


\section{Author's copy-please refer to the published version for the final text: \\ Paula Westenberger, "Copyright protection of illegal street and graffiti artworks" in Bonadio E (ed) Copyright in Street Art and Graffiti: A country-by-country legal analysis (CUP 2019)}

any artwork would possibly not be covered against destruction, regardless of it having been legally or illegally created, and in any case an integrity violation would require a harm to the honour or reputation of the author. In Canada, it is questionable whether it would be possible for a graffiti artist to enforce moral rights against owners of property who wish to erase the graffiti from their property, not only in view of lack of clarity as to whether the right of integrity covers erasing or destruction, but also in view of public policy and doctrine of clean hands. ${ }^{48}$

In civil law jurisdictions, despite the assumption that they would provide stronger moral rights regimes, there is still scope for a balanced approach in view of conflicting interests. In Colombia, for example, graffiti placed on someone's property without their permission cannot affect the property rights of the owner of the building, and thus the property owner could be entitled to remove the graffiti without violating integrity rights. ${ }^{49}$ Similarly, in Greece, "[i]n conflicts between copyright and property rights regarding the destruction of graffiti art, the unauthorised and illegal nature of the activity is more likely to shift the balance towards the owner of the material support." 50

In France, '[c]ourts are not sympathetic to the claims of authors whose work is illegally on another's property'. ${ }^{1}$ But a judgment by the Tribunal of Grande Instance is an example of the balance of interests that a court may undertake in a case of illegal street art. ${ }^{52}$ The court held that squatters who wished to prevent the destruction of a mosaic had two months to remove it at their own cost, and it was significant to this

bis of the Berne Convention. See also Laddie, Prescott and Vitoria, (n 36) para 38.29, arguing that it is unclear whether the UK CDPA gives an author a right to prevent or object to the destruction of a work created by them but owned by someone else, noting this would be subject to the destruction being prejudicial to the author's honour or reputation.

${ }^{48}$ See the chapter by Pascale Chapdelaine in this volume.

${ }^{49}$ See Chapter 9 by Marcela Palacio Puerta in this edition, citing the case Gabriel Antonio Calle $v$ Centro Comercial San Diego P.H., Dirección Nacional de Derecho de Autor, Referencia: 1-201534057, and noting that: "because the artist had been authorised to paint the mural on the wall of the defendant, the latter had an obligation to respect the artist's integrity right. In other words, the Office hinted that a different outcome would have occurred if the artist had painted the wall without the property owner's authorisation; in such a case, the rights of the owner of the property would have prevailed, quite understandably, over the artist's integrity right."

${ }^{50}$ See the chapter by Svratoula Karapapa.

${ }^{51}$ Elizabeth Adeney, The Moral Rights of Authors and Performers: An International and Comparative Analysis (OUP 2006) 190-191, as cited in Chapter 11 by Shane Burke in this edition.

52 TGI Paris, 3rd Ch.,13 October 2000, Benjamin Aichouba et autres $v$ Francis Lecole. See the chapter authored by Shane Burke in this volume. 


\section{Author's copy-please refer to the published version for the final text: \\ Paula Westenberger, "Copyright protection of illegal street and graffiti artworks" in Bonadio E (ed) \\ Copyright in Street Art and Graffiti: A country-by-country legal analysis (CUP 2019)}

case that the work in question 'could be detached from the wall without causing its destruction', also being noted that the right to remove works raise 'issues about the quantification of the indemnity due to the owner of the tangible object., ${ }^{53}$ Burke notes that "[ $t]$ he balancing exercise conducted between the rights of the authors and the property owners would seem to have limited application in relation to graffiti or street art that cannot easily be removed from its given location", 54 which bears remarkable resemblance to the approach adopted in the US in the English case.

In Germany, the Pictures on the Berlin Wall case has held "self-evident that [the owner of property] must also remain free to destroy a work of art (albeit protected by copyright) that is thrust upon him against his will"; however, "[e]ven if the owner must in principle be granted the right to destroy the work, that does not mean that he is also generally entitled to exploit the work economically; for the interference with his property rights that has occurred by itself only justifies the removal of the work, but not its independent economic exploitation". ${ }^{55}$ It is interesting to note that only the owner of the material carrier would have the right to authorize the whitewashing of the graffiti. ${ }^{56}$

\section{Rationales for protection of illegal graffiti as copyright works from an international copyright and human rights law perspective}

As discussed in the previous section, the illegality of graffiti may impact on the eligibility for copyright protection. Certain acts associated with the graffiti subculture are perceived as linked not only to criminal acts and damage of public or private property but also to desecration, which may influence the view on whether copyright should be giving protection to such works. ${ }^{57}$

\footnotetext{
${ }^{53}$ Maria Mercedes Frabboni, 'France' in Gillian Davies \& Kevin Garnett (eds), Moral Rights (2nd edn, Sweet and Maxwell 2016) 428, note 84, citing André Lucas, Henri-Jacques Lucas \& Agnès LucasSchloëtter, Traité de la propriété littéraire et artistique (LexisNexis 2012) 486. On this case, see also Adrian Sterling, Sterling on World Copyright Law (5th edn, Sweet and Maxwell 2018) 271.

${ }^{54}$ See the chapter by Shane Burke in this volume.

${ }^{55}$ Re Pictures on the Berlin Wall [1997] ECC 553 at [11]. Similarly, the chapter authored by Anke Moerland and Stephanie de Potter on the Dutch scenario states that: while removal by a property owner would be lawful, "arguably the removal for the purpose of exposing or offering for sale the artwork against the will of the artist may not be considered a reasonable exercise of a property right."

${ }^{56}$ See the chapter by Marc Mimler in this volume.

${ }^{57}$ See Iljadica (n 2) 106 and, on desecration, see the chapter by Nandita Saikia in this edition.
} 
The Berne Convention for the Protection of Literary and Artistic Works, however, protects "literary and artistic works". ${ }^{58}$ This is a broad category that graffiti and street art works, as either artistic or perhaps even literary works, can in theory perfectly fit in. ${ }^{59}$ It is worth remembering that it is generally understood that copyright protection does not pass judgment on the artistic or literary quality or merit of a work. ${ }^{60}$ Therefore, the challenges mentioned above faced by illegal graffiti should not result in the denial copyright protection to such works.

Indeed, the Berne Convention itself contains a few provisions that seek to facilitate the eligibility of copyright protection. One of them is the provision that states that the enjoyment and exercise of copyright shall not be subject to any formality. ${ }^{61}$ Another provision worth mentioning is that which recognizes copyright protection to derivative works, ${ }^{62}$ arguably even where they have not been authorized by the original copyright owner. Although the caveat that protection is given "without prejudice to the copyright in the original work" ${ }^{63}$ could guarantee the original owners' right to seek remedies against the unauthorized use, it would arguably not allow such owners to use the derivative work without permission of the author of the derivative work, thus effectively giving protection to an illegally produced work. The rationale here is that this form of intellectual activity should be protected. ${ }^{64}$

As stated by Bently, Sherman et al, "copyright may subsist in a derivative work even though it may infringe copyright in the original work" ${ }^{65}$ A question arises whether,

\footnotetext{
${ }^{58}$ Art 2, Berne Convention.

${ }^{59}$ I remind, however, the discussion in various chapters in this book regarding the difficulty of some street artworks in meeting requirements for protection such as fixation and originality. This chapter on the other hand will not concentrate on such aspects as the object of study here is merely whether the illegality of these works should impact in the copyright protection, and therefore it will be assumed that the works would have passed other subsistence factors such as those mentioned.

${ }^{60}$ See Copinger (n 12), paras 3-03; 3-36 and 3-106; Sam Ricketson and Jane C Ginsburg, International Copyright and Neighbouring Rights, The Berne Convention and Beyond (Oxford University Press 2006) para 8.04; Claude Masouyé, Guide to the Berne Convention for the Protection of Literary and Artistic Works (Paris Act, 1971) (WIPO 1978) 13, para 2.4. See also, in the UK, the protection of artistic works "irrespective of artistic quality" in s4(1)(a) of the UK CDPA 1988

${ }^{61}$ Art 5(2), Berne Convention.

${ }^{62}$ Art 2(3), Berne Convention.

${ }^{63}$ Art 2(3), Berne Convention.

${ }^{64}$ Masouyé (n 64) for example, asserts that this provision protects derivative works as original works as their creation calls for intellectual effort, at 19.

${ }^{65}$ Bently, Sherman et. al., Intellectual Property Law (5th edn, OUP 2018) 94.
} 


\section{Author's copy-please refer to the published version for the final text: \\ Paula Westenberger, "Copyright protection of illegal street and graffiti artworks" in Bonadio E (ed) Copyright in Street Art and Graffiti: A country-by-country legal analysis (CUP 2019)}

even though subsistence is confirmed for such infringing works, they would be unenforceable for reasons of public policy, Bently et al explain that, "the courts have generally been willing to enforce copyright in derivative works even though they infringe. This has been explained on the basis that if protection were to be denied to such works, it would lead to a substantial injustice." ${ }^{\prime 66}$ The excerpt below by Goff $\mathrm{J}$ is worth highlighting:

"It is understandable that the owner of copyright should be entitled to restrain publication of an infringing work; but the idea that he should be entitled to reap the benefit of another's original work, by exploiting it, however extensive such work might be, however innocently it might have been made, offends against justice and common sense." ${ }^{67}$

By analogy, the same understanding could arguably be applied to illegal graffiti: protection should be given on the basis that it is an intellectual and creative activity, and on the basis that a commercial exploitation of graffiti works would lead to injustice to authors. ${ }^{68}$

The adoption of the Berne Convention in 1886 was said to be underpinned by "the twin claims of justice to authors and universal benefit to mankind that would be conferred through the international protection of authors' rights". ${ }^{69}$ In this respect, the declarations below by the Assembly of the Berne Union make clear the purpose of incentivizing creativity that justifies the copyright system:

"copyright is based on human rights and justice and that authors, as creators of beauty, entertainment and learning deserve that their rights in their creations be recognized and effectively protected both in their own country

\footnotetext{
${ }^{66}$ Bently, Sherman et al (n 69) 123-124.

${ }^{67}$ Chappell v Redwood Music [1982] RPC 109, 120. See also the discussion in section 2.2 above regarding the UK, including on ZYX Music GmbH v King [1995] FSR 566.

${ }^{68}$ Although this analogy would not apply to the US, where infringing works are not protected, it has been argued that works otherwise illegally created should receive copyright protection, including illegal graffiti, see: Celia Lerman, 'Protecting Artistic Vandalism: Graffiti and Copyright Law' (2013) 2 NYU J. Intell. Prop. \& Ent. L. 295, 316-318.

${ }^{69}$ Sam Ricketson and Jane C Ginsburg, International Copyright and Neighbouring Rights, The Berne Convention and Beyond (Oxford University Press 2006), para 1.30; Sam Ricketson, The Berne Convention for the Protection of Literary and Artistic Works (Kluwer 1987), 891; Copinger (n 12) paras 23-04 and 23-05.
} 


\section{Author's copy-please refer to the published version for the final text: \\ Paula Westenberger, "Copyright protection of illegal street and graffiti artworks" in Bonadio E (ed) Copyright in Street Art and Graffiti: A country-by-country legal analysis (CUP 2019) \\ and in all other countries of the world."}

"the law of copyright has enriched and will continue to enrich mankind by encouraging intellectual creativity and by serving as an incentive for the dissemination throughout the world of expressions of the arts, learning and information for the benefit of all people." 70

This justification is also supported by a human rights analysis of the protection afforded to authors within the cultural rights framework in article 15 of the United Nations International Covenant on Economic Social and Cultural Rights 1966 (ICESCR), which "recognize the right of everyone: (a) To take part in cultural life" and "(c) To benefit from the protection of the moral and material interests resulting from any scientific, literary or artistic production of which he is the author."71 The protection of the moral and material interests of authors "seeks to encourage the active contribution of creators to the arts and sciences and to the progress of society as a whole". ${ }^{72}$ The ICESCR also states that the steps to be taken by State Parties for "the full realization of this right shall include those necessary for the conservation, the development and the diffusion of science and culture." 73

It is important to note that the framework of article 15 ICESCR include the obligation by States to provide an appropriate system of enforcement, and a State would be in violation by omission through "the failure to enforce relevant laws or to provide administrative, judicial or other appropriate remedies enabling authors to assert their rights under article 15, paragraph 1 (c)." ${ }^{, 74}$ This could arguably justify why it would

\footnotetext{
${ }^{70}$ Declarations reproduced in 'Centenary of the Berne Convention: Celebration of the Hundredth Anniversary of the Berne Convention' (1986) 22 Copyright 373. See also Eric Barendt, Freedom of Speech (2nd edn, OUP 2005) 254, who states that copyright "was instituted to reward and promote creativity."

${ }^{71}$ Art 15(1), ICESCR.

${ }^{72}$ UN Committee on Economic, Social and Cultural Rights, General Comment no. 17 (2005): The right of everyone to benefit from the protection of the moral and material interests resulting from any scientific, literary or artistic production of which he or she is the author (article 15, paragraph 1 (c), of the Covenant), UN doc. E/C.12/GC/17, 12 January 2006 (“CESCR General Comment 17”), para 4.

${ }^{73}$ Art 15(2), ICESCR.

${ }^{74}$ CESCR General Comment 17 (n 76), para. 43. See also para 18(a), discussing the element of availability of remedies: "effective administrative, judicial or other appropriate remedies, for the protection of the moral and material interests of authors must be available within the jurisdiction of the States parties".
} 
not be sufficient to recognize the subsistence of copyright but fail to provide appropriate remedies and damages, as seen in section 2 above.

But do graffiti and street art qualify as culture? "Culture" is a very difficult concept to define; it constitutes a social phenomenon covering "all forms of creativity and expression of groups or individuals, both in their ways of life and in their artistic activities", and not merely those forms of creative activities produced by the cultural elites. $^{75}$

When discussing the regulation over the use of public spaces as one of the practices that impact on the right to freedom of artistic expression, UN Special Rapporteur in the field of cultural rights Ms Farida Shaheed addresses the cultural relevance of the use of public spaces for artistic expression, with express reference to graffiti, adding that:

"The use of public space for art is crucial as it allows people, including marginalized people, to freely access, enjoy and sometimes contribute to the arts, including in its most contemporary forms. In some cases, artistic expressions and creations are used in public spaces as a peaceful way of manifesting dissent or alternative viewpoints."

Differently from what many may argue, ${ }^{77}$ graffiti can represent precisely a way out of

\footnotetext{
${ }^{75}$ UNESCO Recommendation on Participation by the People at Large in Cultural Life and their Contribution to It, Nairobi, 1976, Preamble, para 5(a) and art 3(a). See also Paula Westenberger, 'Cultural Palimpsests: Artistic Reuses in Brazil in the Context of Copyright and Human Rights' (PhD thesis, Queen Mary University of London 2017) 190; UNESCO Universal Declaration on Cultural Diversity, Paris, 2001, Preamble, para. 5; Fribourg Declaration on Cultural Rights, article 2 (definitions), (a); UN Committee on Economic, Social and Cultural Rights (CESCR), General Comment no. 21, E/C.12/GC/21, 21 December 2009, paras 11 and 13; Orit Fischman Afori, 'Human Rights and Copyright: The Introduction of Natural Law Considerations into American Copyright Law' (2004) 14(2) Fordham Intellectual Property, Media \& Entertainment Law Journal, 515; Elsa Stamatopoulou, Cultural Rights in International Law: Article 27 of the Universal Declaration of Human Rights and Beyond (Martinus Nijhoff Publishers 2007) 5, 108-09.

${ }^{76} \mathrm{UN}$, Human Rights Council, Report of the Special Rapporteur in the field of cultural rights, Farida Shaheed: 'The right to freedom of artistic expression and creativity', UN doc. A/HRC/23/34, 14 March 2013. This report focuses on the right to the freedom indispensable for artistic expression and creativity, under article 15 ICESCR and article 19 of the International Covenant on Civil and Political Rights (ICCPR).

${ }^{77}$ Explaining the New York politicians' argument that 'graffiti, not poverty, created an environment for subway crime", see Gregory J Snyder, 'Graffiti media and the perpetuation of an illegal subculture' 2(1) Crime, Media, Culture 93.
} 
criminality, ${ }^{78}$ and has indeed opened up career paths for many artists. ${ }^{79}$ The perception of graffiti as art is not only shared by the members of the subculture, but also by many who view these works on the streets or in galleries; the artistic core present amongst members of this subculture not only allows them "to connect with non-deviant opportunities" but also fosters a "culture of learning" within the subculture, while "illegal spaces remain more culturally and symbolically lucrative for many writers" $" 80$

Thus, granting copyright protection to illegal artworks should not be seen as encouraging vandalism, but as a way of securing a fair treatment to a diverse segment of the artistic community against possible forms of commercial misappropriation of their work. Indeed, as stated by Iljadica, "a normative claim might usefully be made here for the protection of graffiti writing (and also street art) in order to promote a diverse culture". ${ }^{81}$ The justification of illegally created graffiti based on cultural rights thus shifts the public policy and public interest based arguments from denying copyright to encouraging protection for these authors.

It is true that "the human right to protection of authorship is not simply a synonym for, or reference to, copyright protection" and that "stronger' copyright protection does not necessarily advance the material interests of creators". 82 However, what is being discussed here is a basic level of copyright protection, which paired with the relevant balancing mechanisms with competing interests (as will be discussed later in this chapter) would allow a balanced system that would protect at least those basic demands against commercial misappropriation, while preserving legitimate interests

\footnotetext{
${ }^{78}$ See Heitor Alvelos (chapter 1 in this edition) reference to Susan A. Phillips, 'Wallbangin': graffiti and gangs in L.A. (University of Chicago Press, 1999) 313: "[...] kids in lower income neighborhoods with established gang activity recognized hip-hop graffiti crews as an alternative to the gangs they acknowledged as ultimately destructive to themselves and others."

${ }^{79}$ See Ronald Kramer (chapter 2 in this edition) and Gregory Snyder, Graffiti lives: Beyond the tag in New York's urban underground (New York University Press, 2009).

${ }^{80}$ MacDiarmid and Downing, (n 2) 605, 612 and 616. Note also the remark regarding the "considerable artistic talent" mentioned in a criminal case on graffiti $R v$ Pease and Others [2008] EWCA Crim 2515 [14] (Judge QC)

81 See Iljadica (n 2) 103.

${ }^{82}$ UN, Human Rights Council, Report of the Special Rapporteur in the field of cultural rights, Farida Shaheed: 'Copyright policy and the right to science and culture', UN doc. A/HRC/28/57, 24 December 2014, paras [29] and [48].
} 


\section{Author's copy-please refer to the published version for the final text: \\ Paula Westenberger, "Copyright protection of illegal street and graffiti artworks" in Bonadio E (ed) Copyright in Street Art and Graffiti: A country-by-country legal analysis (CUP 2019)}

of affected parties such as building owners. ${ }^{83}$

Discriminating against illegal graffiti and street artists to deny copyright protection may also arguably conflict with the principle of non-discrimination in the ICESCR. ${ }^{84}$ Not every street artist will be able to obtain authorization to place their work in public spaces. ${ }^{85}$ Also, the ethos of illegality permeates this artistic practice as a possible creative choice made by these artists. ${ }^{86}$

Approaching the cultural relevance of illegal practices as a form of conceptualizing the merits of copyright protection to illegal graffiti is in no way an absolute protection to these artists. There are ways in which copyright protection could conflict with legitimate interests of other parties involved, such as owners of buildings and even the protection of cultural heritage in certain protected neighbourhoods. ${ }^{87}$ It is interesting to note, however, the current role of certain councils in fighting the removal of graffiti works. ${ }^{88}$ As stated by Kramer, "city councils often sought to preserve or protect works of street art that, although produced without permission, had become venerated." $" 89$ This arguably shows that there can be cultural and social value in works that have been illegally created.

The granting of copyright, as stated, does not necessarily override conflicting interests, as a balance of interests can take place to assess which should be given more

\footnotetext{
${ }^{83}$ Ibid, at [48]: "An appropriate balance is crucial, recognizing that creators are both supported and constrained by copyright rules."

${ }^{84}$ According to CESCR General Comment 17 (n 76), one of State's core obligations is "to ensure equal access, particularly for authors belonging to disadvantaged and marginalized groups"

${ }^{85}$ Shaheed's 2013 report (op cit) [at 68] refers to the various difficulties encountered by people engaged in creative activities in public spaces, "including (a) the bureaucracy's reluctance and tardiness in granting free use of public spaces; (b) arbitrariness in the granting of permits and requirements to obtain multiple authorizations from various authorities; (c) censorship over content before authorization is granted", etc.

${ }^{86}$ See (n 2).

${ }^{87}$ By analogy, balancing freedom of artistic expression and cultural heritage protection, see ECtHR, Ehrmann and SCI VHI v France, application no. 2777/10, judgment of 7 June 2011 (decision on admissibility) (Extracts -Translation). The restoring of a building façade, which was "in total disharmony with the neighbouring buildings", to their previous condition was a justified restriction to freedom of expression in view of the public interest in the protection of heritage. ECtHR, 'Information Note on the Court's case-law' (no. 142, June 2011) 27-28 <http://www.echr.coe.int/Documents/CLIN_2011_06_142_ENG_888406.pdf $>$ accessed 23 December 2018.

${ }^{88}$ See Peter Bengtsen's chapter in this volume, citing the Haringey council example.

${ }^{89}$ See Ronald Kramer's chapter in this volume, citing Jane Preston, Graffiti War (Channel 4, Movie/documentary, 2011).
} 
weight in the specific circumstances. Maintaining the analogy with Art 2(3) of the Berne Convention, any parties affected by the illegal nature of the graffiti could seek the appropriate remedies where available, as the protection of copyright in the graffiti would be without prejudice of the conflicting property interests of owners of the tangible property where the graffiti was illegally placed.

In view of the above, aware of the significance of graffiti artworks to creativity and culture, it would go against the purpose and ethos of copyright law to leave graffiti works unprotected. It can be concluded that the purpose of international copyright protection is to make justice to authors, as justified by their contribution to creativity, and therefore the protection of street art by copyright law is aligned with its purpose to incentivise and reward creativity, culture and the arts.

\section{Seeking a balance of interests considering the main stakeholders involved and the purposes of copyright protection}

As seen above, the discussion on the illegality of the street art and copyright protection will mainly involve the following stakeholders, apart from the street artist claiming copyright protection: (i) owners of property and (ii) commercial users such as advertisers.

On one hand, copyright "should be neutral towards works created by illegal means",90 particularly due to the unfairness of illegality justifying the commercial exploitation of that work by a third party. On the other hand, it would appear fair not to give graffiti artists unlimited moral rights to complain about the destruction of unsolicited works. ${ }^{91}$ This chapter argues that in relation to the rights of owners of buildings to remove unsolicited graffiti, there are stronger arguments to justify cleaning a wall by city councils or owners of buildings if the graffiti was unsolicited. However, copyright should still be able to be used against direct commercial uses, such as reproductions for sale of graffiti works.

\footnotetext{
${ }^{90}$ Celia Lerman, 'Protecting Artistic Vandalism: Graffiti and Copyright Law' (2013) 2 NYU J. Intell. Prop. \& Ent. L. 295, 316; Bonadio (n 44) 104.

${ }^{91}$ Bonadio (n. 44) 105-106.
} 


\section{Author's copy-please refer to the published version for the final text: \\ Paula Westenberger, "Copyright protection of illegal street and graffiti artworks" in Bonadio E (ed) Copyright in Street Art and Graffiti: A country-by-country legal analysis (CUP 2019)}

\subsection{Illegal graffiti and the interests of owners of property}

There are two ways in which we could see an owner of tangible property engaging with illegal graffiti. The first is white-washing of illegal graffiti and the right of integrity and the second is removing illegal graffiti for sale, such as selling a piece of wall embodying a graffiti work.

In relation to white-washing, examples of balanced approaches in relation to the rights of owners of buildings to remove the unsolicited graffiti can be found in countries such as France, ${ }^{92}$ Germany, Colombia and United States, as seen in section 2. The optimal balance could be seen where the artist was given the opportunity to remove the work if at all possible (see France and United States). Depending on the case it could be appropriate to require that the author purchased the tangible support where the artwork was placed. ${ }^{93}$ Another possibility would be to offer the artist the opportunity to at least document the work before destruction.

In relation to the economic exploitation of the works, the German approach appears to offer an appropriate outcome, recognizing that owners of property can destroy the work, but cannot commercially exploit it. ${ }^{94}$ After all, there are differences between intangible intellectual property and the tangible object materializing the work, ${ }^{95}$ and while owners of property may have the right to restore their property to the original state, they should not be able to exploit commercially the intangible work. ${ }^{96}$

Furthermore, removing the work from the street, even if on one's own wall, for personal gain, goes against the ethos of street art, as can be extracted from this

\footnotetext{
${ }^{92}$ In France, there are various property rights that could clash with the copyright of graffiti artists, and "it is interesting to see how French courts seek to balance the competing rights": see Chapter 11 by Shane Burke in this volume.

${ }^{93}$ Particularly in Roman Law-based legal systems, it is interesting to make an analogy with the tabula paintings references in the Institutiones of the second-century jurist Gaius: "if painting is in the hands of the dominus tabulae, the painter can get it back by paying the price of the tabula", see Marta Madero, Tabula Picta: Painting and Writing in Medieval Law (Penn 2004) 6.

${ }^{94}$ See discussion in section 2.2.3.

${ }^{95}$ See for example Article L111-3 of the French Intellectual Property Code, which states that "[t]he intangible property defined by Article L111-1 is independent of ownership of the physical object."

${ }^{96}$ See also Sterling (57) 270, reporting the already cited Berlin Wall Pictures case: "the owner may remove the picture ... but this does not imply that he has the right to sell the work". See also Iljadica (n 2) 107.
} 


\section{Author's copy-please refer to the published version for the final text: \\ Paula Westenberger, "Copyright protection of illegal street and graffiti artworks" in Bonadio E (ed) \\ Copyright in Street Art and Graffiti: A country-by-country legal analysis (CUP 2019)}

passage that articulates the "commonly held belief that street artworks are meant for the public and that their removal for personal gain is wrong - regardless of whether such extraction is lawful. Consequently, removed street artworks are often referred to as 'stolen', even when that description is not accurate in a legal sense." 97

\subsection{Illegal graffiti and misappropriation by commercial third parties}

Examples of such practices of unauthorized exploitation of street art include the dispute between H\&M and Revok; cases in fashion, ${ }^{98}$ fast food, ${ }^{99}$ entertainment $^{100}$ etc. As summarized by Kramer, "[i]n what would appear to be something of a pattern, lawsuits often arise when corporations feature the work of artists in advertising materials, and sometimes product design, without first seeking permission". ${ }^{101}$

The main issue here, as seen in section 2 , is that the current uncertainty in relation to the eligibility or enforceability of copyright in relation to illegal graffiti can be used by commercial third parties to justify their use, monetisation or otherwise taking advantage of graffiti works without seeking permission or remunerating such authors.

However, doctrines such as unclean hands should not be applied to cases of commercial misappropriation of graffiti works, in particular as "the illegal behaviour of the street or graffiti artist does not have a negative impact on the individual or organisation which has misappropriated the illegally placed art (it instead negatively affects the owner of the property upon which the work is placed, which however is not party to the proceeding)." ${ }^{102}$ As stated in section 2.1, the unclean hands doctrine only applies "where the wrongful acts in some measure affect the equitable relations between the parties". ${ }^{103}$ Indeed, to allow such a doctrine to operate in such

\footnotetext{
${ }^{97}$ Peter Bengtsen, in this volume, citing his book The Street Art World (Almendros de Granada Press, 2014) 86ff.

${ }^{98}$ See for example Williamset. Al v. Roberto Cavalli S.p.A. et al., cv 14-06659; Joseph Tierney v. Moschino S.P.A., 2:15- cv-05900.

${ }^{99}$ See Berreau v McDonald's Corporation et al, 2:16-cv-07394.

${ }^{100}$ See Fasoli and others v. Voltage Pictures, LLC, The Zanuck Co d/b/a Zanuck Independent, Mediapro Pictures, Well Go USA Inc, Amplify Releasing, David Warren, Terence Vance Gilliam, and John Does 1-10, U.S. District Court for the Northern District of Illinois, No. 14-cv-06206.

${ }^{101}$ See Kramer's chapter in this volume.

102 Bonadio (n 44) 103-104.

${ }^{103}$ Keystone Driller Co. v. General Excavator Co., 290 U.S. 240, 245 (1933), as cited by Schwender (n
} 


\section{Author's copy-please refer to the published version for the final text:}

Paula Westenberger, "Copyright protection of illegal street and graffiti artworks" in Bonadio E (ed)

Copyright in Street Art and Graffiti: A country-by-country legal analysis (CUP 2019)

circumstances would have the bizarre "effect of legitimizing [the graffiti work's] cooption but not its creation", ${ }^{104}$ which appears to go against the ethos of international copyright and human rights protection, as advanced in section 3. An analogy was also made previously in relation to the protection of unauthorized derivative works, which merit copyright protection due to the creativity invested in the work, as a matter of justice and fairness.

Kramer's interviews with street artists in NY show that they are not in principle adverse to the commodification or to engaging with commercial agents out of the subculture, but that they would expect to be rewarded for their creative outputs, as discussed in his Chapter 2 in this edition.

Within the cultural rights framework discussed in section 3, the "moral and material interests" of authors can be applicable to justify the protection that copyright may provide against such commercial misappropriations, as one of the rationales of this framework is to secure adequate and just remuneration for authors. ${ }^{105}$ Furthermore, measures to protect and promote the diversity of cultural expressions "may also aim at preventing the signs, symbols and expressions of a particular culture from being taken out of context for the sole purpose of marketing or exploitation by the mass media."106

\section{Disadvantages of copyright protection: is copyright really needed?}

There may be problems associated in recognizing copyright protection of illegal graffiti. One of the problems is the question whether "legalizing" illegal graffiti through awarding copyright would go against the deviant nature of the graffiti subculture and the reason why some writers choose to write illegally in the first place, i.e. as a form of cultural or social resistance. ${ }^{107}$ However, the constant clash between

\footnotetext{
10) at 269.

${ }^{104}$ Jamison Davies, Art Crimes?: Theoretical Perspectives on Copyright Protection for IllegallyCreated Graffiti Art (2013) 65 Me. L. Rev. 27, 51.

${ }^{105}$ CESCR General Comment 17 (n 76), paras 4 and 15.

${ }^{106}$ UN Committee on Economic, Social and Cultural Rights, General Comment no. 21: Right of everyone to take part in cultural life (art. 15, para. 1(a), of the International Covenant on Economic, Social and Cultural Rights), UN doc. E/C.12/GC/21, 21 December 2009.

${ }^{107}$ See, for example, MacDiarmid and Downing (n 2) 608, stating that "'Legitimate" spaces for writing graffiti challenge the resistance-focused origins of graffiti subculture'. See also Andrea Mubi
} 


\section{Author's copy-please refer to the published version for the final text: \\ Paula Westenberger, "Copyright protection of illegal street and graffiti artworks" in Bonadio E (ed) \\ Copyright in Street Art and Graffiti: A country-by-country legal analysis (CUP 2019)}

legality and illegality is already present in the graffiti subculture, particularly in view of graffiti's growing mainstream nature. ${ }^{108}$ In any case, and from a legal perspective, recognizing copyright protection should not be seen as legalizing the practice, as much as recognizing copyright in unauthorized derivative works does not result in legalizing of the latter practice. The illegal nature of graffiti as a possible reason why "graffiti writers may eschew copyright laws in favour of the internal regulation of their creativity" 109 is of course still relevant in relation to the regulation of the behavior of the participants of the graffiti subculture. What is argued here is that copyright will be needed to regulate the behavior precisely of those outside of the subculture, such as in cases of commercial appropriation.

Another problem is related to the fact that many street artists are anonymous or deliberately unknown. The reasons for such relate to the fact that "authors could consider the risks of revealing their identities to be too high to be prudent"110 and that "[n]on-commissioned artists may be deterred from claiming copyright in their works because asserting authorship, before the extinction of limitation, may invite prosecution. $^{111,}$

This creates a problem for seeking permission to use, and we may be facing here an example of an orphan work. ${ }^{112}$ However, this should not be considered an obstacle to granting a balanced form of copyright protection, as discussed in the previous sections, as the benefits outweigh such obstacles, particularly in countries that have already adopted a solution for orphan works. In any case, orphan works is a wider issue that should be addressed in countries that still do not contemplate a solution.

Even though graffiti artists may not wish to take immediate action against infringement, they may in the future, particularly "after the statute of limitation had

Brighenti, 'At the wall: Graffiti writers, urban territoriality, and the public domain' (2010) 13(3) Space and Culture, 315-332 and Imuris Valle and Eduardo Weiss 'Participation in the figured world of graffiti' (2010) 26(1), Teaching and teacher education, 128-135.

${ }^{108}$ MacDiarmid and Downing (n 2) 608 explain that 'the increasingly mainstream nature of graffiti culture underscores the reality that there is a constant friction between legal and illegal subcultural involvement'.

${ }^{109}$ Iljadica (n 2).

${ }^{110}$ See the chapter by Nandita Saikia in this volume.

${ }^{111}$ See Chapter 19 by Jonathan Barret in this volume; and Enrico Bonadio, (n 2) 196.

${ }^{112}$ Bonadio (n 2) 196. 
expired: in these cases artists or their heirs may nurture a strong interest in bringing legal actions.","113

In any case, allowing copyright protection would protect those graffiti artists that wish to benefit from the system, while those who prefer to remain anonymous or not engage with copyright would still be able to do so.

Another issue in conceptualising the real need for copyright is that in practice other measures have been taken by street artists to defend their interests. These vary from a system of authentication of street art when it is put on sale, ${ }^{114}$ to the engagement with social media to boycott third parties that are misappropriating the graffiti. ${ }^{115}$ However, not all graffiti artists will have the social media reach of Revok or Stik, or the capacity to secure a settlement to compensate for the misappropriation. Indeed, as argued by Baldini, "[i]nformal strategies such as public shaming and negative discourse, which Peter Bengtsen discusses in this volume, are not enough to protect the works of street artists who are not popular and are likely to find it difficult to make their voices heard." $" 116$

For this reason, it would be appropriate that a system was in place to protect the moral and material interests of these creators, in view of the human rights framework discussed in section 3. This chapter believes that a balanced copyright system, informed by the cultural rights framework could be well suited to address the concerns of graffiti artists, including against commercial appropriation. In the context of article 15(1) of the ICESCR, "participation in culture" could be considered a guiding principle or justification for copyright protection, allowing a system of

\footnotetext{
${ }^{113}$ See chapter 7 in this volume by Enrico Bonadio.

${ }^{114}$ Note Stik "only authenticates the sale of public artworks when it is for the benefit of the community." <http://stik.org/news/2018/12/18/missing-stik-mural-to-be-returned > accessed 10 January 2019. The lack of authentication and public statements by the street artists disapproving of the removals and sale of their works can be a way to remedy this situation without the need for a copyright system to be in place - see the chapter by Bergsten in this volume.

${ }^{115}$ Arguably the approach by Revok against H\&M. Note also the chapter by Kramer in this volume, on "resisting corporate appropriation", the role of social media etc.

${ }^{116}$ See the chapter by Baldini in this volume.
} 


\section{Author's copy-please refer to the published version for the final text: \\ Paula Westenberger, "Copyright protection of illegal street and graffiti artworks" in Bonadio E (ed) \\ Copyright in Street Art and Graffiti: A country-by-country legal analysis (CUP 2019)}

securing moral and material interests that would take into consideration the particularities of a specific subculture, instead of a mere commodification rationale. ${ }^{117}$

\section{Conclusion}

This chapter has investigated the impact of illegality of graffiti and street art in copyright protection. This illegality was framed in relation to the way the work was placed, rather than its content. It was found that mainly in common law jurisdictions, there is still uncertainty as to whether copyright provides appropriate protection to unauthorized graffiti works, which predominantly involves discussion on enforcement and remedies.

From the analysis of the Berne Convention and the ICESCR, it was argued that (a) an analogy could be made between the protection of unauthorized derivative works with illegal graffiti: protection should be given on the basis that it is an intellectual and creative activity, and any parties affected by the illegal nature of the graffiti could seek the appropriate remedies where available and (b) from a human rights perspective, in particular within the cultural rights framework, creators of illegal graffiti should be given protection to their moral and material interests, and this protection involves the country providing effective enforcement mechanisms.

An analysis of the conflicting interests has concluded that (i) owners of property and (ii) actions by commercial third parties are the most problematic conflicts to be resolved. Suggestions for an appropriate balance of interests have been made, including that owners of property should have the right to remove unsolicited graffiti but giving the chance when possible for the artist to remove or document the work. In any case, unauthorized commercial exploitation of unsolicited or illegal graffiti should not be allowed simply by virtue of the fact that these works have been placed illegally.

\footnotetext{
${ }^{117}$ I advance this argument in more detail in Paula Westenberger, 'Cultural Palimpsests: Artistic Reuses in Brazil in the Context of Copyright and Human Rights' (PhD thesis, Queen Mary University of London 2017)
} 